\title{
Indonesian Capital Punishment in Comparative Perspective
}

\author{
Dave McRae \\ Senior Research Fellow, Asia Institute, University of Melbourne \\ david.mcrae@unimelb.edu.au
}

\begin{abstract}
Indonesia's execution of 14 narcotics prisoners in 2015 was a surprise. Capital punishment has been a persistent feature of Indonesia's legal system, but Indonesia had previously conducted few executions. New president Joko Widodo gave no prior signal that he strongly supported capital punishment. This article undertakes a comparative analysis of Indonesia's use of capital punishment under Widodo and his predecessor, Susilo Bambang Yudhoyono. It finds capital punishment has persisted despite the presence of up to six of seven factors comparative scholars hold to be determinants of abolition. Its persistence shows political leadership supportive of capital punishment to be a formidable obstacle to abolition, even when many other determinants are manifest. The Indonesian case suggests that factors that shift debate away from capital punishment's merits are most likely to spur abolition. Chief among these is the imperative to protect citizens from the death penalty abroad, a factor unanticipated in the international literature.
\end{abstract}

\section{Keywords}

Indonesia - death penalty - political science - capital punishment - law abolition

Indonesia grabbed global headlines in 2015 by executing 14 narcotics prisoners during the first half of the year. The killings attracted global attention because 12 of the 14 prisoners killed were foreigners, including the citizens of several abolitionist countries. Brazil, the Netherlands, and Australia each made the symbolic protest of withdrawing their ambassadors temporarily after their

(C) DAVE MCRAE, 2017 | DOI: 10.1163/22134379-17301002

This is an open access article distributed under the terms of the Creative Commons 
citizens were executed. The executions also drew criticism from the United Nations Secretary General.

Beyond the identities of those put to death, the executions also garnered attention because they were a surprise. Capital punishment has been a persistent feature of the Indonesian legal system, but over the past three decades Indonesia has averaged only two executions per year, with just seven of those put to death being narcotics prisoners. ${ }^{1}$ Fourteen narcotics executions in six months was thus a sharp departure from previous practice.

Adding to the surprise, this escalation was enacted by a new president, Joko Widodo, whom few had predicted would be a strong supporter of capital punishment. Widodo had not discussed his views on capital punishment publicly ahead of the July 2014 presidential election, and his meteoric rise to the presidency directly from local politics meant he had no relevant track record on this issue. Whereas his rival for the presidency pitched himself to voters as a firm leader, Widodo had campaigned on a platform of open, accountable government, including respect for human rights (Jokowi-JK 2014:8-9; 26-7).

If the executions were unexpected if viewed through a country-specific lens, what might we learn by applying a comparative perspective? It is the latter approach that this article adopts. Identifying seven factors commonly held in comparative studies to be determinants of abolition, this article first questions whether an analysis of Indonesia's death penalty practice in terms of these seven factors would lead us to expect Indonesia to abolish the death penalty. The article applies these seven factors both to the presidency of Joko Widodo (2014-), just entering its third year at the time of writing, and to that of Widodo's predecessor, Susilo Bambang Yudhoyono (2004-2014). Yudhoyono provides an apt point of comparison, as the length of his administrationstretching for two five-year terms-allows for thorough investigation of the effects of the seven factors. Finding a majority of these factors manifest in Indonesia during both presidencies but the death penalty nevertheless persistent, the article then investigates what the Indonesian case can tell us about whether and how these factors contribute to death penalty abolition.

1 Unless otherwise indicated, all death penalty statistics in this article are drawn from the datasets of Indonesian NG Os Kontras (Komisi Orang Hilang dan Korban Tindak Kekerasan, Commission for the Disappeared and Victims of Violence) and Imparsial, reconciled to eliminate inconsistencies, and supplemented with media reportage. 


\section{Global Trends in Capital Punishment}

Two facts about capital punishment frame most comparative studies of the death penalty. First, the proportion of abolitionist countries worldwide has more than doubled in the past three decades, with $55 \%$ of countries having abolished the death penalty either for all or for ordinary crimes as of June 2016 (Amnesty International 2016). Second, there has been a clear reduction in the number of executions in most countries-some say virtually all countries - that do retain the death penalty (Hood and Hoyle 2015:19). ${ }^{2}$ This second trend applies even to China, which by current estimates nevertheless continues to execute more people annually than the rest of the world combined. $^{3}$

Several regions remain as concentrations of retentionist countries. Johnson identifies four remaining strongholds: the United States, which along with Japan is the only high-income democracy in the world to retain capital punishment; the Carribean; the majority Muslim countries of the Middle East; and Asia (Johnson 2010:337).

Of these regions, Johnson and Zimring (2009) dub Asia the 'next frontier' for capital punishment in both theory and practice. In practice, because they estimate that of people living in retentionist countries, three quarters are in Asia, with the region responsible for $90 \%$ of executions globally. If abolition is to spread worldwide, they observe, then the majority of change will take place in Asia. In theory, because whether or not change takes place in Asia, we will learn more from the region about the factors that contribute to the retention or abolition of capital punishment.

On these terms, Indonesia's population of around 240 million people makes it a significant case for study, even if it has conducted few of the judicial executions in Asia in recent decades. Elsewhere I have argued for Indonesia's significance owing to the potential for changes in its death penalty practice to have a domino effect on the death penalty regimes of its Southeast Asian neighbours (McRae 2012).

2 Although, according to Amnesty International figures, executions actually increased by $14 \%$ between 2012 and 2013, before decreasing by $22 \%$ between 2013 and 2014. These figures do not include executions in China, where precise data are not available. See The Economist, 273-2014.

3 Aurélie Plaçais (2014). 'China's "efforts to gradually reduce the application of the death penalty"', http://www.worldcoalition.org/china-executions-statistics-capital-crimes-dui-hua .html (accessed 11-11-2016), and 'China executes more people than rest of world combined, Amnesty International reveal', news.com.au, 1-4-2015 (accessed 11-11-2016). 


\begin{tabular}{|c|c|c|c|c|c|}
\hline & $\begin{array}{l}\text { Johnson } \\
\text { \& Zimring } \\
(2009)\end{array}$ & $\begin{array}{l}\text { Hood } \\
\text { \& Hoyle } \\
(2009)\end{array}$ & $\begin{array}{l}\text { Neumayer } \\
(2008)\end{array}$ & $\begin{array}{l}\text { Greenberg } \\
\text { \& West } \\
(2008)\end{array}$ & $\begin{array}{l}\text { Bae } \\
(2009 ; \\
2012)\end{array}$ \\
\hline Democratization & $\mathrm{y}$ & & $\mathrm{y}$ & $\mathrm{y}$ & $\mathrm{y}$ \\
\hline Political leadership & $\mathrm{y}$ & $\mathrm{y}$ & $\mathrm{y}$ & & $\mathrm{y}$ \\
\hline $\begin{array}{l}\text { Economic } \\
\text { development }\end{array}$ & $\mathrm{y}$ & & $\mathrm{n}$ & $\mathrm{n}^{*}$ & \\
\hline $\begin{array}{l}\text { Capital punishment } \\
\text { as a human-rights } \\
\text { issue }\end{array}$ & $\mathrm{y}$ & $\mathrm{y}$ & $\mathrm{y}$ & na & $\mathrm{y}$ \\
\hline $\begin{array}{l}\text { External pressure } \\
\text { for abolition }\end{array}$ & $\mathrm{y}$ & $\mathrm{y}$ & $\mathrm{y}$ & na & $\mathrm{y}$ \\
\hline Regional dynamics & $\mathrm{y}$ & & $\mathrm{y}$ & na & $\mathrm{y}^{*}$ \\
\hline $\begin{array}{l}\text { Existing low } \\
\text { execution rates }\end{array}$ & ambivalent & $\mathrm{y}$ & na & $\mathrm{n}$ & na \\
\hline
\end{tabular}

* indirectly, as a possible contributor to greater political rights, y $\mathrm{y}=$ yes, $\mathrm{n}=$ no, na $=$ not applicable

What factors might spur a country to abandon the death penalty? Johnson and Zimring are among the comparative scholars who have sought to identify the determinants of abolition. Table 1 shows the recurrence of seven factors across five recent studies on abolition.

The first recurring factor is the importance of democracy or democratization. Scholars observe that countries often abolish capital punishment in the early stages of democratization to distance themselves from their authoritarian past. As observed previously, among high-income democracies, only Japan and the United States retain the death penalty, and only half of the states in the us have conducted an execution during the past decade. ${ }^{4}$

A second recurring factor is political leadership. Leaders, often from leftwing governments (Neumayer 2008:251; Greenberg and West 2008:322), frequently abolish the death penalty against prevailing public opinion (Neumayer 2008:250).

4 On the death penalty at state level in the United States, see 'United States of America, death penalty worldwide', http://www.deathpenaltyworldwide.org/country-search-post.cfm ?country=United + States + of + America $($ accessed 11-11-2016). 
A third factor, economic development, divides opinion. Johnson and Zimring argue that increasing economic development encourages moves towards abolition without being a necessary or sufficient condition (Johnson and Zimring 2009). Scholars adopting a quantitative approach have found no correlation between economic development and the death penalty, however. Greenberg and West (2008:320), for example, conclude that '[n]o measure of economic activity significantly predicts the death penalty'. Neumayer (2008:259), similarly, found that adding per-capita income to his regression model had no significant effect on the likelihood of abolition.

Fourth, scholars cite the emergence of capital punishment as a humanrights issue, rather than a matter of criminal justice. This framing makes capital punishment a reputational issue. It has also led to the emergence of various international human-rights instruments that set standards for when the death penalty may be applied, or call for a moratorium on its use or for its abolition. The International Covenant on Civil and Political Rights, for example, limits the application of the death penalty in retentionist countries only to the most serious crimes upon the final judgement of a competent court.

The framing of the death penalty as a human-rights issue also facilitates a fifth factor, namely external pressure for abolition. In this context, Hood and Hoyle highlight the European Union and its member states as having been particularly active in exerting political pressure (Hood and Hoyle 2009).

Regional dynamics are a sixth factor. Neumayer (2008:259) finds the likelihood of abolition increases as the proportion of abolitionist countries in a region increases. The increasing likelihood of abolition may reflect the enactment of binding, regional human-rights charters (Bae 2012:217-30), or other diplomacy. Notably, scholars identify the absence of intra-regional pressure in Asia as a factor supporting retention (Johnson and Zimring 2009; Bae 2012).

A seventh factor, low rates of executions, again divides scholars. Hood and Hoyle (2009) give greatest credence to this factor, arguing that abolition is generally a matter of time once capital punishment ceases to play an important practical role in the criminal justice system. Johnson and Zimring (2009) also observe that most countries which abolished the death penalty during the second half of the twentieth century were able to do so at 'practically no pecuniary cost and without the need to refashion their systems of criminal justice or crime control' owing to their low rates of execution. They acknowledge, however, that the path from low rates of execution to abolition remains uncertain, a point made with greater force by Greenberg and West. The latter express scepticism that abolition can be inferred from the long-term low use of capital punishment. Few executions may generate little opposition, they argue, and thus little incentive to abolish (Greenberg and West 2008:335). 
Beyond these seven factors, most of these scholars also discuss the role of Islam as a possible impediment to abolition, although again opinion is divided. The empirical fact that most countries with majority Muslim populations retain the death penalty is clear. What quantitative scholars question is whether it is Islam per se that promotes retention, or whether majority Muslim countries simply tend to exhibit the political characteristics associated with retention of the death penalty.

\section{The Death Penalty under Yudhoyono}

This section analyses Indonesia's death penalty practice under the government of Susilo Bambang Yudhoyono through the analytical lens of the seven factors outlined in the previous section. Between 2004 and 2014, Yudhoyono oversaw 21 executions: 3 for terrorism, 5 for narcotics, and 13 for murder. Of these executions, 16 were conducted in his first term in government, with only 5 executions in his second term, all in a single year.

\section{Deteminants of Abolition}

Yudhoyono assumed power soon after Indonesia had essentially completed its post-authoritarian democratization process. Democratization included a fundamental overhaul of Indonesia's legal system: four constitutional amendments between 1999 and 2002 established the underpinnings of the democratic order, including a constitutional bill of rights; the courts were made institutionally independent of the government; and draconian political laws were revoked or revised (Crouch 2010). This impulse to distance itself from its authoritarian past, common to many democratic transitions, did not extend to revoking the death penalty, however. The death penalty remained a part of Indonesia's criminal code, and new anti-corruption (1999) and anti-terrorism (2003) legislation extended the death penalty to new offences. Indonesia's courts also continued to hand down death sentences under democratic rule, if anything at a greater rate than during the late authoritarian period (McRae 2012:5).

The pattern of executions under Yudhoyono does not suggest that he harboured any particular enthusiasm for capital punishment, but nor did he exercise consistent political leadership in opposition to the death penalty. The Yudhoyono government conducted executions only in five of the ten years he was in power, albeit including what was then the peak year of executions in 2008. During his second term in particular, Yudhoyono's government also took a number of steps to lessen Indonesia's use of the death penalty. He conducted no executions during the first three years of this second term, as part 
of a four-year moratorium, easily the longest pause in executions in Indonesia during the past 30 years. During this pause, Yudhoyono granted clemency to four prisoners on death row for narcotics-related crimes, having stated during his first term as president that he would not do so. Yudhoyono also reportedly granted clemency to at least one prisoner on death row for murder, although reports of this decision only emerged after he had concluded his second term. ${ }^{5}$ Finally, Indonesia also abstained in a United Nations General Assembly vote in 2012 on a call for a worldwide moratorium on the death penalty, having voted against two previous resolutions under Yudhoyono's rule (United Nations 2012; Donatelli 2012). When these steps became known publicly and became controversial, Yudhoyono reverted relatively swiftly to conducting executions, however, as his government put five people to death during the course of 2013. Nor is the author aware of a single public statement made by Yudhoyono during his rule or afterwards that is critical of the death penalty, highlighting the limits of the steps he took to lessen Indonesia's use of this punishment.

Nor does Yudhoyono's term in office offer any evidence for the salience of increasing economic development to the prospects of abolition. Yudhoyono oversaw a decade of consistently rapid economic growth, consistent with a period of rapid economic growth in Indonesia spanning decades, during which Indonesia's per-capita GDP increased roughly sixfold between 1961 and 2010 (Hill 2015:286). This prolonged economic growth, dented significantly only by the 1997-1998 Asian financial crisis, has seen Indonesia become a middleincome country. Death penalty practice has essentially remained unaltered over this period, however.

The framing of capital punishment as a human-rights issue was visible during the Yudhoyono years in three legal challenges to the death penalty on human-rights grounds. None succeeded. In its decisions on two of these cases, Indonesia's Mahkamah Konstitusi (Constitutional Court) acknowledged the limitations placed on the death penalty by international human-rights instruments, but also found that Indonesia's death penalty practice already falls within these limitations. A 2007 decision by Indonesia's Constitutional Court on the legality of the narcotics law in effect acknowledges the limitation of the death penalty to 'the most serious crimes', the condition established under the International Covenant on Civil and Political Rights (ICCPR), which Indonesia ratified in 2005. Anomalously, the court found that particularly serious narcotics crimes were able to satisfy this 'most serious crimes' test, meaning that

5 'Presiden Kabulkan Grasi Terpidana Mati Asal Sintang', Lintas Kapuas, 22-1-2015 (accessed 1511-2016). 
international human-rights law did not restrict the range of offences for which Indonesia imposes the death penalty. ${ }^{6}$ In a second case, filed in 2008 , the court also found that the pain caused by non-instantaneous death in executions conducted by firing squad did not amount to torture. Such pain was simply an inevitable by-product of the lawful act of executing a prisoner, the court found. ${ }^{7}$ A third case, filed in 2012, did not mount a coherent argument against the death penalty, and was dismissed almost exclusively on the grounds that the legal principles raised had already been tested in the narcotics law case in 2007.8

Yudhoyono's foreign minister, Marty Natalegawa, also acknowledged the human-rights dimension of capital punishment in 2012 when he cited a global trend towards abolition of the death penalty because it conflicted with human rights, and said Indonesia was itself headed in that direction. ${ }^{9}$ Supporters of the death penalty within other ministries were able to overrule such pro-abolition statements, however. In this specific instance, the coordinating minister for political, legal and security affairs directly contradicted Natalegawa in the same press conference, held in Jakarta, to explain the government's granting of clemency to several death row inmates, saying: "The global trend is provided as background and for information. It doesn't mean we will just follow the global trend. 10

Indonesia did not face concerted external pressure to abolish the death penalty during the Yudhoyono administration, but the effects of foreign advocacy were visible, if not decisive. The international attention spurred by the 21 executions conducted under Yudhoyono was muted because 17 of the executed prisoners were Indonesians, whereas the 4 foreigners to face the firing squad came from countries who did not advocate actively for their citizens. Nevertheless, Indonesian law enforcement officials did occasionally cite external pressure, particularly from European governments. The Deputy Attorney General for special crimes spoke out in support of the proposed abolition of the death penalty for corruption in 2011, for example, saying it impeded Indonesia's cooperation with other countries to extradite fugitives and recover assets. ${ }^{11}$

6 Putusan Mahkamah Konstitusi Republik Indonesia (Indonesian Constitutional Court Decision) No. 2-3/PUU-v/2007.

7 Indonesian Constitutional Court Decision No. 21/PUU-VI/2008.

8 Indonesian Constitutional Court Decision No. 15/PUU-X/2012.

9 'Indonesia Segera Hapus Hukuman Mati', Kompas.com, 26-10-2012 (accessed 15-11-2016).

10 'Menko Polhukam: Hukuman Mati Masih Berlaku', rmol.co, 16-10-2012, (accessed 11-112016).

11 'Penghapusan hukuman mati bakal permudah pengembalian aset', mediaindonesia.com, 30-3-2011. 
Also in 2011, the head of the Badan Narkotika Nasional (B NN, National Narcotics Agency), Gories Mere, attributed a move away from death sentences for drugs crimes by Indonesia's courts at the time to pressure by foreign NG OS and European governments. ${ }^{12}$ Mere's comments cannot be taken entirely at face value, however. BNN is a core supporter of the death penalty, and Mere's claims of foreign influence on court decisions were likely a tactic to press for greater use of capital punishment.

Regarding regional dynamics, neither the few abolitionist Southeast Asian countries nor Indonesia's neighbours in the broader Asian region applied pressure for Indonesia to abolish the death penalty under Yudhoyono. Nor is it obvious that Southeast Asia's three abolitionist states-the Philippines, Cambodia, and Timor-Leste-or Asia's two other abolitionist states-Nepal and Bhutan-could have exerted a strong influence on Indonesia, either individually or collectively. Another of Indonesia's neighbours, Australia, did make representations to Indonesia in opposition to the application of the death penalty. These representations were undermined by Australian-government support for the execution of three perpetrators of the 2002 Bali bombings in 2008, however. ${ }^{13}$ Australian advocacy was likely also restrained because several of its citizens occupied Indonesia's death row for much of the Yudhoyono era. Throughout this period, Australia refrained from publicly criticizing executions when they occurred in Indonesia, in contrast to several European states. The government may have feared that vocal advocacy would jeopardize the fate of these citizens, if it spurred a nationalist backlash within Indonesia. Only in 2015 did Australia shed these shackles in its public rhetoric, as it became clear that the execution of two Australian citizens was imminent.

Nor did low rates of execution generate significant pressure for abolition in Indonesia under Yudhoyono. Although Indonesia averaged just 2.1 executions per year during his administration, senior political leaders and law enforcement officials nevertheless appeared to regard the death penalty as an important criminal punishment. Officials frequently expressed confidence that executions would have a deterrent effect on crime, that the most serious crimes merit the death penalty, and that unrepentant or recidivist criminals deserve death (McRae 2012:9). Such rhetoric was most visible regarding narcotics cases. Indonesia's National Narcotics Agency in particular argued that the death penalty was needed to combat a 'drugs emergency' within the country, and

\footnotetext{
12

'Pasca Uu baru, tidak ada gembong narkoba yang dihukum mati', detik.com, 27-12-2011, (accessed 11-11-2016).

13 Numerous Indonesian interlocutors have raised Australia's stance on the 2008 Bali bomber executions when discussing death penalty politics in Indonesia.
} 
highlighted the arrest of various narcotics prisoners on charges of controlling the drugs trade from behind bars as evidence that the death penalty was a necessary punishment. ${ }^{14}$

In fact, the primary effect of low rates of execution under Yudhoyono appeared to be to limit the degree of concerted opposition to the death penalty. In general, Indonesia's abolitionist movement does not comprise organizations or individuals who devote themselves solely to campaigning for abolition. Instead, the movement consists primarily of human-rights organizations and lawyers for whom abolition is simply one of a range of responsibilities. ${ }^{15}$ When few executions take place, these organizations and lawyers devote much of their energies to other issues.

In summary, Indonesia under Yudhoyono exhibited six of the seven proposed determinants of abolition. Four of those factors-democractization, economic development, framing of the death penalty as a human-rights issue, and low rates of execution - were unequivocally present. A further two factors were weakly present: Indonesia faced limited external pressure to abolish and Yudhoyono exercised inconsistent leadership on the issue. Although the president imposed a four-year moratorium on executions, he resumed executions when it became publicly known that he had taken steps to decrease Indonesia's use of executions, triggering political pressure on him.

Despite the presence of six of seven factors, there was no sign that Indonesia was any closer towards abolishing the death penalty at the end of Yudhoyono's presidency. Moreover, beyond these factors, Islamic doctrine also made a visible contribution to support for the death penalty under Yudhoyono. Muslims comprise $87 \%$ of Indonesia's population, according to the 2010 census, ${ }^{16}$ and there are numerous examples of Muslims explaining their support for the death penalty in Islamic terms. Speaking in 2013, one of the three pro-death penalty commissioners on Indonesia's National Commission for Human Rights

14 '“... UNODC dan Kepala BNN Anang ISKANDAR: Indonesia SUDAH Masuk KONDISI Darurat NAR КОВA ..."', NRM News, 21-2-2013, https://nrmnews.com/2013/02/21/unodc-dan -kepala-bnn-anang-iskandar-indonesia-sudah-masuk-kondisi-darurat-narkoba/ (accessed 14-11-2016).

15 Organizations such as Kontras, Imparsial, Migrant Care, Komisi Nasional Anti Kekerasan Terhadap Perempuan (Komnas Perempuan, National Commission on Violence Against Women), Lembaga Bantuan Hukum (LBH, Legal Aid Institute) and Komisi Nasional Hak Asasi Manusia (Komnas HAM, National Commission for Human Rights) all have much broader remits than death penalty campaigning alone.

16 'Penduduk Menurut Kelompok Umur dan Agama yang Dianut', Sensus Penduduk 2010, http://sp2010.bps.go.id/index.php/site/tabel?tid=320\&wid=o (accessed 11-11-2016). 
listed Islam as a reason for his stance, for example. His mother had told him upon his appointment, 'You can be wrong in the eyes of people, but don't be wrong in terms of religion', the commissioner said. ${ }^{17}$ More generally, rightwing Islamic groups have also been among the most vocal opponents of abolition.

Analysing Indonesia's death penalty practice only in terms of these seven factors, however, overlooks the single factor that generated the most pressure to abolish capital punishment during the Yudhoyono administration. This factor is the imperative to protect Indonesian citizens facing execution abroad. During the final three years of Yudhoyono's government, this imperative showed strong potential to build broader opposition to capital punishment in Indonesia. A comparative analytical framework misses this factor, because existing studies do not anticipate the scenario of a retentionist country actively advocating for its own citizens overseas. Examining the effect of Indonesia's advocacy abroad on its domestic death penalty debate is nevertheless important both in its own right, and because it helps us to understand better why other factors did not generate strong pressure for abolition under Yudhoyono.

\section{A New Factor-Protecting Citizens Abroad}

It was the execution of a female Indonesian domestic worker in Saudi Arabia in mid 2011 - two years into Yudhoyono's second term - that made the imperative to protect citizens facing the death penalty abroad a prominent political issue in Indonesia. This execution struck a particularly raw nerve for Indonesians, because Indonesian migrant workers frequently experience maltreatment at the hands of their employers, making them uniquely sympathetic figures. Public outcry within Indonesia included sharp criticism of the Indonesian government for its perceived inaction, spurring an immediate response to prevent further executions. Most notably, the government formed an ad hoc task force comprising government officials, lawyers, and civil-society figures to advocate for all Indonesians facing the death penalty abroad, not just migrant workers. ${ }^{18}$ This task force rendered Indonesia's domestic and foreign policy on the death penalty starkly at odds. Overseas, Indonesia opposed

17 'Inilah Alasan Seorang Komisioner Komnas HAM Setuju Penerapan Hukuman Mati', rmol.co, 1-7-2013 (accessed 11-11-2016).

18 To form the task force, Yudhoyono issued Keputusan Presiden (Presidential Decision) No. 17/2011 titled Satuan Tugas Penanganan Kasus Warga Negara Indonesia/Tenaga Kerja Indonesia Di Luar Negeri Yang Terancam Hukuman Mati (A Task Force to Handle Indonesian Citizens/Migrant Workers Facing the Death Penalty Overseas). 
the death penalty for its citizens regardless of their crime. Within its borders, Indonesia continued to apply the death penalty.

The immediate priority for this task force was diplomacy to prevent further executions, which included Yudhoyono writing personally to foreign governments, as well as visits of eminent Indonesians to countries where its citizens faced the death penalty. The government also paid blood money (diyat) to free several Indonesians facing execution for murder in Saudi Arabia. ${ }^{19}$ The task force also established a network of lawyers on retainer in priority countries to ensure that Indonesians received adequate legal representation. Previously, according to one task force member, Indonesia's diplomatic missions in Saudi Arabia did not have sufficient budget to engage a Saudi lawyer even for a single case. ${ }^{20}$ When the task force was disbanded, in 2012, Indonesia's foreign ministry and its migrant worker placement and protection agency resumed responsibility for advocacy. Overall, Yudhoyono claimed in his final independence day address in August 2014, the government had helped 190 Indonesians to avoid the death penalty (Yudhoyono 2014).

This government advocacy emboldened abolitionists within Indonesia, because it enabled them to argue for an end to executions without debating the merits of the death penalty directly. Standard abolitionist arguments against capital punishment - based on international human-rights norms and the question of deterrence claims, or highlighting the danger of irreversible punishment based on wrongful convictions, all the more so in a judicial system in which corruption is endemic - have generated little traction in Indonesia because of majority support for the death penalty. ${ }^{21}$ Almost as soon as Indonesia's intensified overseas advocacy commenced, various Indonesians instead made the pragmatic argument that continuing to apply the death penalty within Indonesia undermined Indonesia's moral basis to advocate abroad for its own citizens. ${ }^{22}$ These arguments have particular traction because a majority

19 'Pembayaran Diyat Darsem Gunakan Anggaran Perlindungan ткI', Liputan6, 13-07-2011 http://news.liputan6.com/read/343756/pembayaran-diyat-darsem-gunakan-anggaran -perlindungan-tki (accessed 11-11-2016); 'Masih Ada 54 TKI Terancam Mati di Arab', Viva News, 21-3-2012 (accessed 14-11-2016).

20 Author's interview with a member of the Indonesian task force, June 2012.

21 Although public opinion polling is infrequent and does not always use rigorous methodology, survey results consistently show support for the death penalty of around $75 \%$. Several poll results from 2006 and 2010 are presented in McRae 2012. More recently, a poll fielded by Indo Barometer in March 2015 found that $84 \%$ agreed or strongly agreed with the death penalty for drug distributors (Indo Barometer 2015).

22 'Koalisi Hati Desak Hapus Hukuman Mati di Indonesia', Tribun News, 22-6-2011 (accessed 11-11-2016). 
of Indonesians appear to believe in the importance of protecting Indonesians abroad, despite support for the death penalty within Indonesia. ${ }^{23}$

Indonesian officials also used the government's advocacy for Indonesians overseas to justify decisions to lessen Indonesia's use of the death penalty domestically. After it became known in 2012 that President Yudhoyono had granted clemency to four prisoners sentenced to death for narcotics crimes, for example, Yudhoyono's foreign minister Marty Natalegawa explicitly linked the decisions to Indonesia's foreign advocacy. Stating that 42 of the 100 Indonesians that the government had helped to escape the death penalty overseas had faced narcotics charges, Natalegawa told journalists: 'So, if we discuss narcotics crimes and the granting of clemency domestically, we also must remember that overseas $45 \%$ of Indonesians are facing the death penalty [for narcotics crimes].24 In subsequent comments, deputy minister for law and human rights Denny Indrayana also stated that it was natural for the president to grant clemency to people sentenced to death in Indonesia, given that the president was also seeking clemency from other countries for Indonesians. $^{25}$

Ultimately, these pragmatic arguments and the protections that Indonesia's foreign advocacy provided against domestic criticism proved insufficient to prevent a resumption of executions under Susilo Bambang Yudhoyono. As criticism of his clemency decisions continued unabated, Yudhoyono's government moved in March 2013 to execute Ademi Wilson, a Malawi or Nigerian national sentenced to death for narcotics crimes. The first person to be executed in more than four years, Wilson turned out to be one of five people to face a firing squad in 2013 .

23 Certainly policy makers believe they face circumstances of majority support for this advocacy, as reflected in the following observation contained in a magazine produced by the Direktorat Perlindungan Warga Negara Indonesia dan Badan Hukum Indonesia (Directorate for the Protection of Indonesian Citizens and Legal Entities): ‘[Elite actors who use Indonesians facing the death penalty as a political commodity to seek popularity] have indirectly caused the opinion to be formed amongst the community that Indonesian citizens who have done wrong or violated the law overseas are heroes that the state must "free" from the captivity of criminals, with no limit to the defences provided [by the state]. See 'Disini wni Paling Banyak Terancam Hukuman Mati', Peduli, March 2015, p. 31 .

24 'Indonesia pun Minta Grasi ke Negara Lain', Republika Online, 17-10-2012, (accessed 11-112016).

25 'Ini alasan sby beri grasi pada terpidana mati kasus narkoba', Merdeka.com, 23-10-2012, (accessed 11-11-2016). 
Nevertheless, the imperative to protect citizens abroad emboldened mainstream senior national figures such as Natalegawa to speak out, for the first time, against capital punishment. Until the public outcry over the female migrant worker, Indonesia's abolitionist movement was dominated by humanrights activists arguing against the merits of the death penalty. They argued that executions have no deterrent effect over and above imprisonment and that the application of the death penalty in sentencing is arbitrary and thus fundamentally unfair and unjust. Neither of these arguments gained traction with policy makers or the public.

Protecting citizens abroad allowed abolitionists to shift debate away from the merits of the death penalty and instead present pragmatic arguments against it that resonated with the Indonesian public. This feature stood out as being of enduring significance.

\section{The Death Penalty under Joko Widodo}

Joko Widodo was inaugurated as president in October 2014, the first politician from outside of Indonesia's authoritarian-era political elite to reach the nation's highest office. His meteoric rise to the presidency meant his view on capital punishment was unknown, particularly as capital punishment did not feature as a campaign issue during the presidential election. His stance became clear within three months of taking office, however, as the new president moved to sharply intensify Indonesia's use of executions, specifically for narcotics crimes. In early December 2014, Widodo announced that he would reject clemency pleas for all 64 prisoners on death row for narcotics, saying his stance was justified by a drugs epidemic. ${ }^{26}$ Widodo began rejecting clemency pleas soon afterwards, and the Attorney General's department conducted two rounds of executions in early 2015. After only six months in office, Widodo's government had already executed 14 prisoners (including 12 foreign citizens), the record number of executions in a single year during democratic Indonesia. As of the time of writing, the government had also conducted four further executions in July 2016.

As the following section sets out, this sudden change in Indonesia's use of the death penalty underlines the central importance of political leadership. All

26 'Jokowi: Empat Persoalan Negara Harus Segera Diatasi', ugm.ac.id, 9-12-14 https://ugm .ac.id/id/berita/9555-jokowi:.empat.persoalan.negara.harus.segera.diatasi (accessed 11-112016). 
five other determinants of abolition that were manifest under Yudhoyono persisted under Widodo. In fact, the shift towards executing foreigners increased external pressure, a factor that was only weakly present under Yudhoyono. The stark escalation of the executions under a new president shows that when the political leadership strongly supports capital punishment, all other factors are secondary.

\section{Determinants of Abolition}

Widodo's early use of the death penalty clearly demonstrates the critical role of political leadership in determining death penalty practices. No other factor can account for the stark change in Indonesia's death penalty policy, as other contextual factors remained essentially unaltered. Executing narcotics convicts served two interests for Widodo. As part of a broader focus on commencing his government with quick wins, executions enabled him to swiftly demonstrate his commitment to improve law enforcement against narcotics crimes. Proceeding with the executions despite international protests also enabled Widodo to present himself as decisive president. With Widodo consequently supportive, long-standing proponents of narcotics executions were able to achieve results they had never managed under Yudhoyono. ${ }^{27}$ Widodo's prodeath penalty stance also all but forecloses the prospects for abolition during his five-year term.

This focus on leadership does raise the question of whether the president is personally responsible for executions in Indonesia. Widodo's own rhetoric on this point has been inconsistent. At times he has sought to play down his role, saying Indonesia's courts and not the president determine whether to hand down the death penalty. By contrast, in a rally with supporters in May 2015, Jokowi portrayed the decision to execute as a personal one: 'I have never talked tough [...] I just gave the order once-do it..28 Such rhetoric notwithstanding, nothing in Indonesian law specifies a time limit for executions once the appeals process has been exhausted, meaning that as the head of government, the president ultimately decides whether to conduct executions or to refrain from doing so.

Widodo's swift intensification of Indonesia's use of executions also emphasizes the absence of a direct relationship between low rates of execution and

27 Widodo's new Attorney General also played a crucial role in pushing for large numbers of executions as soon as possible. For a more comprehensive exposition of the interests underpinning Widodo's execution policy, see McRae 2015.

28 Footage of Widodo's remarks is available at https://youtu.be/XıWTjPPeLWo?t=2h15m26s, accessed 11-11-2016. 
abolition. With all the procedures to conduct executions well established, and majority public support for the death penalty, deciding to increase the number of executions Indonesia conducted required no more than a policy decision on Widodo's part.

In fact, the civil-society response to Widodo's execution plans lends clear weight to Greenberg and West's contention that minimal use of executions in a country is likely to generate little opposition, allowing capital punishment to persist (Greenberg and West 2008:335). Abolitionists were unprepared to counter the president's announcement in December that there would be no mercy for narcotics criminals, and it was not until April 2015 that civil-society groups launched two new legal challenges to the death penalty, the first serious challenges to the punishment in more than five years. ${ }^{29} \mathrm{By}$ this time, six prisoners had already been executed, and a second round of eight executions was

29 Of these cases, one filed with the Mahkamah Konstitusi Republik Indonesia (Constitutional Court) asked the court to interpret the president's constitutional power to grant clemency, and place limits on its exercise, in a bid to have Widodo's blanket rejection of clemency pleas without providing justification in each case declared invalid. The court ultimately ruled that the case could not proceed after the two death row prisoners who were listed as applicants were executed before the court convened a session to hear the case, as it judged that the coalition of NGOs who were co-applicants in the case did not have legal standing to file the case ('MK Putuskan Tidak Dapat Menerima Pengujian uU Grasi', Mahkamah Konstitusi, 11-12-15, http://www.mahkamahkonstitusi .go.id/index.php?page=web.Berita\&id=12556\#.WCVulOF94dU, accessed 11-11-2016). A second judicial review filed with the Mahkamah Agung (Supreme Court) sought to overturn a Supreme Court circular that limited those convicted of crimes to a single judicial review. This circular had resulted in judicial review requests filed by several death row inmates being rejected on procedural grounds. It was not clear at the time of writing whether this case was proceeding or had also been withdrawn. On the latter challenge, see 'MA Diminta Cabut SEmA Peninjauan Kembali', Hukum Online 17-4-2015, http://www .hukumonline.com/berita/baca/lt553ode7fgb271/ma-diminta-cabut-sema-peninjauan -kembali, accessed 11-11-2016. In 2016, the Constitutional Court also decided on two judicial reviews of the clemency law, each of which were filed by death row inmate Suud Rusli, and not by a civil-society coalition. In the first case, the court annulled an article in the clemency law which had required clemency to be filed within one year of a case gaining final legal standing. To prevent use of clemency rights to delay execution, however, the court opined that prosecutors could ask death row inmates or their family whether or not they would be filing for clemency. The court rejected the second application, however, in which Rusli sought to overturn a restriction that limits a prisoner to filing a single clemency plea. See 'M K Batalkan Batasan Waktu Waktu Pengajuan Grasi', Mahkamah Konstitusi, 15-6-2016 http://www.mahkamahkonstitusi.go.id/index.php?page=web.Berita\&id $=13178 \& \mathrm{menu}=2 \#$.WCZcOuF968U, accessed 11-11-2016; 'MK Tolak Gugatan Uji Materi UU 
imminent. Indonesia has few, if any, organizations that solely focus on opposition to the death penalty, meaning that abolitionists must weigh advocacy against other priorities. In this context, the increasing number of executions appeared to elevate capital punishment among the priorities of advocacy organizations.

As uncontroversial as it was within Indonesia to execute narcotics prisoners, Widodo's change of policy also significantly increased the external pressure that Indonesia faced over the death penalty. Whereas the seven foreigners executed under previous democratic-era presidents all came from countries that did not actively advocate for their citizens, Widodo's plan to execute all narcotics prisoners on death row drew many more countries into the fray. Around 18 countries had citizens on death row in Indonesia at the beginning of Widodo's administration, including a number of abolitionist countries. ${ }^{30} \mathrm{In}$ addition to representations made by individual countries, the planned executions also drew criticism from Un Secretary General Ban Ki Moon as well as the office of the UN High Commissioner for Human Rights, amongst others. ${ }^{31}$ Brazil and the Netherlands also temporarily recalled their ambassadors from Jakarta after their citizens were executed in January, and Australia did the same when two of its citizens were executed in April. Brazil also chose to escalate its row with Indonesia by postponing the presentation of credentials to Indonesia's new ambassador-designate, causing Indonesia to recall the diplomat in question. ${ }^{32}$

As the ultimate decision maker on the executions, Widodo was able to disregard this external pressure, because doing so made the executions more beneficial for him politically within Indonesia. Widodo used external pressure to present himself to Indonesian audiences as a firm leader aloof to international entreaties. The president in fact encouraged a nationalist response, describ-

Grasi Antasari dan Suud Rusli', CNN Indonesia, 21-6-2016, http://www.cnnindonesia.com/ nasional/2016o621165614-12-139856/mk-tolak-gugatan-uji-materi-uu-grasi-antasari-dan -suud-rusli/, accessed 11-11-2016.

30 Diane Zhang (2015), 'By the numbers: Indonesia's executions of foreigners', The Drum, http://www.abc.net.au/news/2015-02-26/zhang-indonesia-likely-to-execute-more -foreigners/6263122 (accessed 11-11-2016).

31 'Ban Ki-moon makes plea to Indonesia over executions', The Guardian, 14-2-2015, https:// www.theguardian.com/world/2015/feb/14/tony-abbott-calls-on-indonesia-not-to -execute-bali-nine-pair, (accessed 11-11-2016).

32 'Indonesia withdraws ambassador to Brazil as dispute over executions deepens', $A B C$ News, 20-2-2015, http://www.abc.net.au/news/2015-02-21/indonesia-withdraws-ambassador-to -brazil-in-a-sign-of-a-deepeni/6176370, (accessed 11-11-2016). 
ing the executions as a matter of Indonesia's legal sovereignty. Although this nationalist response arguably created new obstacles for abolitionists, Indonesian activists and sympathetic media nevertheless attempted to use external pressure to make pragmatic arguments against the death penalty. The Indonesian news weekly Tempo called on the government to enact a moratorium following the April executions in view of Indonesia's worsening international reputation. ${ }^{33}$ A group of Indonesian academics and activists also sought to increase external pressure on Indonesia by writing to The Lancet journal to call on the Indonesian government to adopt an 'evidence-informed response to illicit drugs' (Irwanto et al. 2015). Shortly after the April executions prominent Indonesian human-rights lawyer Todung Mulya Lubis also predicted that Widodo would 'slow down a bit' in the interests of being able to participate without issue in international forums (McRae 2015:36). The furore over the 14 executions in early 2015 did appear to significantly delay the conduct of a third round of executions, which eventually took place after a pause of 15 months in July 2016. Although the Attorney General's office had announced prior to the April 2015 executions and the furore that they generated that preparations for this third round were underway, afterwards Prasetyo was instead left to repeatedly justify the deferral of further executions on the grounds that such a deferral would allow his department to focus on contributing to economic development. ${ }^{34}$ It became clear over the first half of 2016 that further executions would take place, however, and Indonesia eventually executed one Indonesia and three Nigerians for narcotics crimes in late July $2016 . .^{35}$

Finally, Widodo's use of the death penalty also further elucidates a factor absent both under Yudhoyono and his own presidency, namely the support for abolition created by regional dynamics. In fact, regional dynamics helped to enable Widodo's choice to intensify executions specifically for narcotics crimes. Narcotics executions remain relatively commonplace within Indonesia's immediate region, even if globally executing narcotics convicts has become rare. In a 2015 work, Hood and Hoyle (2015:161) list just 11 countries worldwide that have conducted a narcotics execution since January 2004. Five

33 'Eksekusi Sensasi Cara Jokowi', Tempo, 4-5-2015. Tempo repeated its call for a moratorium after a further round of executions in 2016, this time citing Indonesia's messy law enforcement. See 'Moratorium Vonis Mati', Tempo, 19-09-2016.

34 'Kejagung Tunda Eksekusi Mati Demi Kawal Pembangunan', cNN Indonesia, 8-9-2015 (accessed 15-11-2015).

35 'Four killed by firing squad, 10 spared as Indonesia carries out latest round of executions', ABC News, 29-07-2016 http://www.abc.net.au/news/2016-07-29/indonesia-carries-out -latest-round-of-executions/7671164 (accessed 15-11-2016). 
of these countries are in Southeast Asia, including Indonesia. With the addition of China, more than half are in Asia. The use of the death penalty for perpetrators of narcotics-related crimes by Indonesia's regional neighbours enabled public figures within Indonesia to depict narcotics executions as a matter of ongoing international debate. ${ }^{36}$ It also facilitated comparisons with the international response to executions in Malaysia and Singapore, depicting criticism of Indonesia's use of the death penalty as exceptional. ${ }^{37}$

\section{Protecting Citizens Abroad under Widodo}

Under President Widodo, the imperative to protect citizens abroad has again demonstrated its potential to alter Indonesia's death penalty practice. Unexpectedly, although two Indonesian female domestic workers were executed in Saudi Arabia in April 2015, it was not these cases that demonstrated this factor's potency. Instead, Widodo's decision to grant a temporary reprieve to a Philippines migrant worker who was to be executed in Indonesia in April again underlined the ability of this issue to exert influence by shifting debate away from the merits of capital punishment.

Saudi Arabia executed the two Indonesian citizens-Siti Zaenab and Karni Binti Medi Tarsim, each convicted of murder-just as Indonesia was finalizing preparations to bring a second cohort of narcotics prisoners before the firing squad. ${ }^{38}$ In contrast to the public uproar over the execution of Ruyati binti Satubi in 2011, these executions drew a relatively muted response within Indonesia, and so did nothing to dissuade Indonesia from itself proceeding with further narcotics executions two weeks later. Migrant worker advocates and humanrights groups criticized the Indonesian government's efforts to save the two women, as they had in 2011, but far fewer mainstream figures added their voices to this criticism. Public figures could not readily criticize the Indonesian government for not doing more to help the women, having for months characterized international advocacy for narcotics prisoners facing execution in Indonesia as amounting to intervention. Arguably, the Indonesian government was also more convincingly able to make the case in 2015 that it had advocated exhaustively for each woman, although similar statements made by the foreign ministry in 2011 were insufficient to deflect criticism. By contrast, Philippines citizen Mary Jane Veloso was able to tap into the same vein of public sympathy within Indonesia to gain an eleventh-hour temporary reprieve from execution

\footnotetext{
36 'detiknews, 20-1-2015', detiknews, 20-1-2015 (accessed 15-11-2016).

37 'Eksekusi Mati Mendapat Sorotan', Kompas, 8-5-2015.

38 'Indonesia kirim protes keras kepada pemerintah Arab Saudi', Antaranews.com, 15-4-2015 (accessed 15-11-2016).
} 
in April. A female migrant worker, Veloso was sentenced to death in 2010 when she was discovered to have 2.6 kilograms of heroin concealed in her suitcase upon arrival in Indonesia. ${ }^{39}$ Her execution was postponed to allow her to testify in the human-trafficking case of her alleged recruiter, who surrendered to Philippines authorities after Veloso had been given three days' notice of her execution.

Veloso's background as a migrant worker enabled Indonesian campaigners to make the case that she was a victim of human trafficking rather than argue directly against the merits of the death penalty for drugs crimes. Indonesian NGO Migrant Care adopted this approach in a meeting with Widodo on the day that Veloso was due to be executed, including drawing parallels between Veloso and Indonesian workers facing the death penalty overseas. ${ }^{40}$ Veloso also received extensive support on social media within Indonesia, as well as supportive coverage in Indonesia's major print media outlets, although some of this was published only after her reprieve. ${ }^{41}$

At the time of writing, it is not clear whether Veloso's case will eventually help to shift broader attitudes within Indonesia on Widodo's intensification of executions. She herself remains under threat of execution. But her case is another example of how the issue of protecting citizens abroad can motivate Indonesians who otherwise support the death penalty to oppose at least some executions.

\section{Conclusion}

Examining Indonesia's death penalty practice in terms of seven factors scholars hold to be determinants of abolition, this article has found a majority of these factors to be manifest under presidents Susilo Bambang Yudhoyono and Joko Widodo, even as each president has made persistent use of executions. The Indonesian case thus suggests the central importance of political leadership to a nation's prospects for abolition. In particular, a political leadership supportive of the death penalty looms as a formidable obstacle to abolition, even when many other determinants of abolition are manifest.

39 Sleman District Court Decision no. 385/PID.B/2010/PN.SLMN, 11 October 2010.

40 Author's interview with Migrant Care activists, May 2015; 'Cerita soal Mary Jane ke Jokowi, Anis Migrant Care Menangis', cNN Indonesia, 29-4-2015 (accessed 15-11-2016).

41 'The Internet Is Begging the Indonesian Government to Spare a Filipina Single Mother's Life', Time, 24-4-2015. 
A further insight from Indonesia is that factors that can shift debate away from the merits of capital punishment are additionally likely to contribute to abolition. In a context where capital punishment is resilient and enjoys majority public support, the death penalty debate entails a vocal minority attempting to change the minds of capital punishment's much larger support base. External pressure is one factor that can generate pragmatic arguments not reliant on debating the merits of capital punishment, but it is a blunt instrument because of its clear potential to generate a nationalist backlash. Instead, a particular insight from the Indonesian case pertains to a factor unanticipated in the comparative literature - the imperative to protect citizens abroad - as the factor most able to shift the terms of the death penalty debate. Under Yudhoyono, this factor allowed abolitionists to justify decreasing use of the death penalty on the basis of pragmatism and consistency. Under Widodo, its clearest effect is manifested in the case of Mary Jane Veloso, whose status as a female migrant worker has tapped into a vein of public sympathy for Indonesians from a similar background. As international mobility increases, the imperative to protect citizens abroad is a factor that scholars should investigate in any country when assessing the prospects for abolition.

\section{References}

Amnesty International (2016). Abolitionist and retentionist countries as of 20 June 2016. https://www.amnesty.org/download/Documents/ACT5038312016ENGLISH.PDF (accessed 15-11-2016).

Bae, Sangmin (2009). 'South Korea's De Facto Abolition of the Death Penalty', Pacific Affairs 82:407-425.

Bae, Sangmin (2012). 'Human security, capital punishment, and East Asian democracies', in: Benny Teh Cheng Guan (ed.), Human security: Securing East Asia's future pp. 217-30. Dordrecht: Springer.

Crouch, Harold (2010). Political reform in Indonesia after Soeharto. Singapore: Institute of Southeast Asian Studies.

Donatelli, Maria (2012). 'UN General Assembly Committee adopts draft moratorium resolution'. http://www.worldcoalition.org/United-Nations-UN-General-Assembly -Committee-vote-moratorium-resolution.html (accessed 15-11-2016).

Greenberg, David F. and Valerie West (2008). 'Siting the death penalty internationally', Law \& Social Inquiry 33:295-343.

Hill, Hal (2015). 'The Indonesian economy during the Yudhoyono decade', in: Edward Aspinall, Marcus Mietzner and Dirk Tomsa (eds), The Yudhoyono presidency:Indonesia's decade of stability and stagnation, pp. 281-302. Singapore: ISEAS. 
Hood, Roger and Carolyn Hoyle (2009). 'Abolishing the death penalty worldwide: The impact of a "new dynamic", Crime and Justice 38:1-63.

Hood, Roger and Carolyn Hoyle (2015). The death penalty: A worldwide perspective. Oxford: Oxford University Press.

Imparsial (2010). Menggugat hukuman mati di Indonesia. Jakarta: Imparsial.

Indo Barometer (2015). 'Kepuasan publik jelang setengah tahun pemerintahan Jokowi$\mathrm{JK}$ '. [Report of national survey fielded $15^{-25}$ March.]

Irwanto, Dewa N. Wirawan, Ignatius Praptoraharjo, Sulistyowati Irianto, Siti Musdah Mulia on behalf of 11 signatories (2015). 'Evidence-informed response to illicit drugs in Indonesia', The Lancet 385:2249-50.

Johnson, David T. (2010). 'Asia's declining death penalty', The Journal of Asian Studies 69:337-46.

Johnson, David T. and Frank Zimring (2009). The next frontier: National development, political change, and the death penalty in Asia. Oxford: Oxford University Press.

Jokowi-JK (2014). 'Jalan perubahan untuk Indonesia yang berdaulat, mandiri dan berkepribadian: Visi misi, dan program aksi'. http://kpu.go.id/ (accessed 15-11-2016).

Kontras (2010). 'Death penalty log 2010'. http://www.kontras.org/data/ Update\%2oDeath\%2oPenalty\%2oLog\%202010\%20-\%2oKontraS.pdf (accessed 1511-2016).

Kontras (2013). Capital punishment in Indonesia: Update 2012-2013. http://kontras.org/ data/Capital\%2oPunishment\%2oin\%2oIndonesia\%2oUpdate\%202012-2013.pdf (accessed 15-11-2016).

McRae, Dave (2012). A key domino? Indonesia's death penalty politics. Sydney: Lowy Institute for International Politics.

McRae, Dave (2015). '“Jokowi” and his firing squads', Strategic Review 5:29-32.

Neumayer, Eric (2008). 'Death penalty: The political foundations of the global trend towards abolition', Human Rights Review 9:243-68.

United Nations (2012). 'General Assembly will call for moratorium on executions, with view to abolishing death penalty, under terms of resolution approved by Third Committee'. http://www.un.org/press/en/2012/gashc4058.doc.htm (accessed 15-112016).

Yudhoyono, Susilo Bambang (2014). 'Pidato kenegaraan presiden Republik Indonesia dalam rangka HUT ke-69 proklamasi kemerdekaan Republik Indonesia di depan sidang bersama Dewan Perwakilan Rakyat Republik Indonesia dan Dewan Perwakilan Daerah Republik Indonesia' [Delivered in Jakarta, 15-8-2014]. 